\title{
Financial Islamic Banking Development and Economic Growth: A Case Study of Jordan
}

\author{
Mohammed Ali Al-Oqool $^{1}$, Reem Okab ${ }^{1} \&$ Mohammed Bashayreh $^{1}$ \\ ${ }^{1}$ Department of Financial \& Administrative Sciences, AL-Huson University College, AL-Balqa' Applied \\ University, Jordan \\ Correspondence: Mohammed Ali Al-Oqool, Department of Financial \& Administrative Sciences, AL-Huson \\ University College, AL-Balqa' Applied University, P.O. Box 50, AL-Huson, 21510, Jordan. E-mail: \\ oqool60@yahoo.com
}

Received: December 30, 2013

Accepted: January 10, $2014 \quad$ Online Published: February 25, 2014

doi:10.5539/ijef.v6n3p72

URL: http://dx.doi.org/10.5539/ijef.v6n3p72

\begin{abstract}
In this paper, an attempt has been conducted to explore the relation between financial Islamic banking development (FIBD) and economic growth (EG) of Jordan over the periods of 1980-2012. Two models have been formulated to indicate this relation within the context of VECM framework. For this purpose, FINC and DEPT are used as a measure of FIBD, while RGDP used as an indicator of EG. The results show that there is bi-directional long-run Granger causality between RGDP and FINC reflecting a positive contribution of Jordanian Islamic banks in financing the process of Jordanian social and economic development. The relation appears to be unidirectional relation between RGDP and DEPT running from RGDP to DEPT reflects the excess liquidity problem that all Jordanian Islamic banks suffer from it. With regarding to short-run causality there isn't any significant relations between FIBD and EG. Taken together, these empirical findings involve valuable information for Jordanian policy makers.
\end{abstract}

Keywords: financial development, economic growth, islamic banking, Jordan

\section{Introduction}

Today a considerable growth of Islamic banks over the last four decades of establishment has been recorded; an estimated growth rate of Islamic financing reached to $15 \%$ over the last ten years (Ilias, 2010).

In Jordan, four Islamic banks are operating; Jordan Islamic Bank (JIB). Which was the pioneer Islamic bank established in Jordan in 1979 (JIB, Annual Financial Report, 1980). The Islamic International Arab Bank (IIAB) established in 1998 (JIB, Annual Financial Report, 1990). Jordan Dubai Islamic Bank (JDIB) established in 2010 (JDIB, Annual Financial Report 2010). Al-Rajhi Bank (RAJ) as branch of Jordan operated at the end of March 2011 (RAJ, Annual Financial Report, 2011). All these banks were supervised by the Central Bank of Jordan (CBJ). By the end of 2012 JIB are conducting their activities through 113 branches (CBJ, Annual Financial Report, 2012).

A notable development of JIB can be viewed in the rapid growing of its assets, credit facilities and deposits; assets grew from (15.5 million JDs) in 1980 to (4669.8 million JDs) in 2012, while credit facilities increased from (6.7 million JDs) in 1980 to (3577.4 million JDs) in 2012, but the growth in time and saving deposits increased from (11.6 million JDs) in 1980 to (2549.5 million JDs) in the end of 2012.

The rapid growth of JIB proved the feasibility of this issue to become an integral part of the Jordanian financial sector acts as an effective financial funding resource for the economic sectors of Jordan. JIB was able to grow rapidly and enhance its position among Jordanian conventional banks, As it presents banking and investment services to the clients in conformity with the Islamic Rules of Sharia' which has a special method of Islamic economy and adopts a vision of money function different from that of conventional banks. A tangential growth in JIB could be proven the following issues:

A- The share of JIB from the total assets of banks operating in Jordan went up from $1.4 \%$ in 1980 , to $11.88 \%$ at the end of 2012. This increase in the share of Islamic banks brought about a reduction in the share of assets of conventional banks operating in Jordan from $98.6 \%$ in 1980 to $88.12 \%$ at the end of 2012. 
B- Total time and saving deposits of JIB changed significantly over the period of 1980-2012. The \%age of time and saving deposits to total Jordanian banking deposits increased from $2.2 \%$ in 1980 to $11.88 \%$ at the end of 2012. In contrast, this increment causes time and saving deposits of conventional banks dropped from $98.6 \%$ in 1980 to $97.7 \%$ at the end of 2012 .

C- Share of JIB from the total credit facilities of Jordanian banks went up from $1.2 \%$ in 1980 , to $19.1 \%$ at the end of 2012. This increase in the share of JIB brought about a reduction in the share of credit facilities of banks operating in Jordan from $98.8 \%$ in 1980 to $80.9 \%$ at the end of 2012 .

Considering the previous issues, an investigation of financial Islamic banking development (FIBD) causality on Jordanian economic growth (EG) becomes a vital one to reveal the contribution of Jordanian Islamic banks in the development process.

The main objective of this paper is to explore the relation between FIBD and EG in Jordan using time series data of total finance of Jordanian Islamic banks (FINC), total Jordanian Islamic time and saving deposits (DEPT) and real gross domestic product (RGDP) over the period of 1980-2012, employing an econometric framework that draws on the finance growth relationship literature. Thus, we formulate the main following hypothesis: There was feedback between FIBD and Jordanian EG.

The remainder of this paper is organized as follows. Next section presents a review of related literature. Section three delineates the model, data, and econometric techniques. Empirical results and discussion presented in section four. Finally section five conclusion and recommendations reported in Section five.

\section{Literature Review}

Most of the studies assessing the impact of financial development (FD) on EG have looked at conventional banks rather than Islamic banks because the importance of the recent has grown only in the last four decades.

To the best of our knowledge, this issue has not yet been extensively studied in the literature of Islamic banks. Limited studies related to Islamic banks have been conducted in the recent years. Such studies for instance are:

Hassanudin et al. (2013) investigated the relationship between FD and EG in Bahrain dual financial system. Co-integration test and VECM were applied. For Islamic finance, the results show a strong long-run relation with bi-directional causality, while it is uni-directional causality running from EG to conventional finance.

Farahani and Dastan (2013) examined the role of Islamic banks financing on EG of selected Islamic countries over the period of 2000-2010. The findings show a significant relation in both short run and long run for the selected countries.

Abduh and Omar (2012) detected the short run and the long run relation between Islamic banking development (IBD) and EG in the case of Indonesia during the period of 2003-2010. The main findings show that the relation appears to be bi-directional for both short run and the long run terms.

Farahani and Dastan (2012) investigated the short run and long run nexus of IBD and EG of Iran and Indonesia. A bi-directional relation in both short run and long run between IBD and EG.

Abduh and Chowdhury (2012) investigated the relation between FIBD and EG in Bangladesh using total financing and total deposits of Islamic banks as measures of FIBD and GDP as an EG measure. The results show a positive and significant short run and long run relationship between FIBD and EG.

Goaied and Sassi (2011) explored the nexus of the IBD and EG in some countries in the Middle East and North Africa (MENA). The results show insignificant relation between FIBD and EG across MENA countries.

Furqani and Mulyany (2009) investigated interactions between IBD (total Islamic bank financing) and EG (real GDP per capita, fixed investment and trade activities) in Malaysia over the period of (1997-2005). The results show that in short-run only fixed investment granger causes Islamic banks to develop, where as in the long-run it appears to be a bi-directional causality relation between IBD and fixed investment.

With regarding to Jordan Islamic banks, this paper is the first attempt to explore the relation between FIBD and the Jordanian EG covering along period from 1980-2012.

\section{Model Specification, Econometric Techniques and Data}

\subsection{Model Specification}

One of the most important issues in assessing the causality relation between financial developments (FD) and EG is how to obtain satisfactory empirical indicators of this issue.

Proceeding from the literature review, this study has chosen, in line with Furqani and Mulyany (2009), the 
relation between EG and FIBD may be specified through the following models:

a-Financing model:

$$
\begin{aligned}
& \operatorname{LRGDP}_{t}=\gamma_{0}+\gamma_{1} \operatorname{LFINC}_{t}+e_{1 a} \\
& \operatorname{LFINC}_{t}=\theta_{0}+\theta_{1} L_{L G D P_{t}+e_{2 a}}
\end{aligned}
$$

b-Deposits model:

$$
\begin{aligned}
L R G D P_{t} & =\alpha_{0}+\alpha_{1} L D E P T_{t}+e_{1 b} \\
L D E P T_{t} & =\beta_{0}+\beta_{1} L R G D P_{t}+e_{2 b}
\end{aligned}
$$

Where, LRGDP is the natural logarithm of Jordanian real GDP as an indicator of Jordanian EG. LFINC, LDEPT are the natural logarithm of total financing and total deposits of Jordanian Islamic banks respectively as a measure of FIBD. $\left(\alpha^{\prime} s, \beta^{\prime} s, \gamma^{\prime} s, \theta^{\prime} s\right)$ are coefficients to be determined and $\left(e_{1 a}, e_{2 a}, e_{1 b}, e_{2 b}\right)$ error terms.

\subsection{Econometric Technique}

The econometric technique we applied consists of three sequential steps. First: to test the stationarity of RGDP, FINC and DEPT series. Second: to detect the existence of cointegration relation between the variables Third: to analyze the Granger causality between EG and FIBD in Jordan.

\subsubsection{Unit Root Test}

To get unbiased results in time series analysis, all time series under concerned should not contain unit root (stationary). As Granger and Newbold, (1974) states that if a series have unit root this leads to produce spurious result.

In order to test for stationary, we employed Augmented Dickey-Fuller (ADF) test (Dickey \& Fuller, 1979). ADF utilized with the inclusion of a constant and a trend for each time series variable.

In $\mathrm{ADF}$, we test the null hypothesis that the series have unit root (non-stationary), against the alternative one that the series is stationary (haven't unit root) by comparing the calculated ADF $\tau$ (tua)-statistics value with the critical $\tau$-statistics value obtained from McKinnon's Table (Enders, 1995; Gujarati, 1995).

Non stationary series leads to difference the time series until stationary is achieved, if the non stationary time series become stationary after differences it (d) times, then we can say that the series is integrated of order (d), i.e. I(d) (Kennedy, 1996; Katos, 2004).

\subsubsection{Co-Integration Test}

The Johansen approach developed by Johansen and Jesulius (1990) and Johansen (1991) used to investigate the possible long-run relation existence between the study variables. Johansen approach uses two test statistics, as suggested by Johansen (1988) and Oseterwald-Lenum (1992) to determine the number of co-integrating vectors. These are the trace test and the maximum Eigenvalue test, represented by equation (3) and (4).

$$
\begin{gathered}
\lambda_{\text {trace }}(r)=-T+\sum_{i=(r+1)}^{n} \ln \left(1-\lambda_{i}\right) \\
\lambda_{\text {max }}(r, r+1)=-T \ln \left(1-\lambda_{r+1}\right)
\end{gathered}
$$

Where $\lambda_{\mathrm{i}}$ is the ith shows the estimated values of the characteristic roots, in assuming that the series are I(1). T, is the number of observations and $\mathrm{r}$, is the rank of the vector matrix.

We test the null hypothesis of Trace test that there is at most $(r)$ co-integrated relation against the alternative one that there are more than $(r)$ co-integrated relations. In other words, a rejection of the null hypothesis means that there are more than $(r)$ co-integrated relations. The Trace test rejects the null hypothesis if the trace statistics exceeds the critical value. On the other hand, we test the null that there is $(r)$ co-integrated relation versus $(r+1)$ co-integrated relations. The test rejects the null hypothesis if the Eigenvalue test statistics exceeds the respective critical value. If the null hypothesis for both statistics is rejected, this indicates that there is one co-integrated relation among the variables under testing.

\subsubsection{Granger Causality}

Granger causality concept (Granger, 1969; 1980) states that if two variables (say: X, Y) are co-integrated and each is individually integrated of order one, e.i. I(1). Then either $X$ causes $Y$ if and only if the past values of $X$ help to predict the changes of $\mathrm{Y}$ or $\mathrm{Y}$ causes $\mathrm{X}$ if and only if the past values of $\mathrm{Y}$ help to predict the changes of $\mathrm{X}$.

Assuming the presence of co-integrating vector among the variables in finance and deposits models, the Granger 
causality test based on the VECM can be formulated as follows:

a-Financing model

$$
\begin{gathered}
\Delta L R G D P=\gamma_{0}+\sum_{i=1}^{p} \gamma_{1} \Delta L R G D P_{t-i}+\sum_{i=1}^{p} \gamma_{2} \Delta L F I N C_{t-i}+\delta_{1} E C T_{t-1}+u_{t} \\
\Delta L F I N C=\theta_{0}+\sum_{i=1}^{p} \theta_{1} \Delta L F I N C_{t-i}+\sum_{i=1}^{p} \theta_{2} \Delta L R G D P_{t-i}+\delta_{2} E C T_{t-1}+u_{t}
\end{gathered}
$$

b-Deposits model

$$
\begin{aligned}
& \triangle L R G D P=\alpha_{0}+\sum_{i=1}^{p} \alpha_{1} \Delta L R G D P_{t-i}+\sum_{i=1}^{p} \alpha_{2} \Delta L D E P T_{t-i}+\delta_{3} E C T_{t-1}+u_{t} \\
& \triangle L D E P T=\beta_{0}+\sum_{i=1}^{p} \beta_{1} \Delta L D E P T_{t-i}+\sum_{i=1}^{p} \beta_{2} \Delta L R G D P_{t-i}+\delta_{4} E C T_{t-1}+u_{t}
\end{aligned}
$$

Where, LFINC and LDEPT are the natural log of total finance and total deposits of Jordanian Islamic banks respectively. ECTt-1 is the error correction term contains the long-run information, since it is derived from the long-run cointegrated relationship. (ut's) is the uncorrelated white noise residual. P is the optimal lag lengths. To investigate the long-run causality the following hypotheses are tested:

1-FINC does not Granger causes RGDP if $H_{0}: \gamma_{2}=0$ against the alternative $H_{a}: \gamma_{2} \neq 0$ FINC Granger causes RGDP. (Equation 5-a);

2-RGDP does not Granger causes FINC if $\mathrm{H}_{0}: \theta_{2}=0$, against the alternative $\mathrm{H}_{\mathrm{a}}: \theta_{2} \neq 0$ RGDP Granger causes FINC. (Equation 5-b);

3-DEPT does not Granger causes RGDP if $\mathrm{H}_{0}: \alpha_{2}=0$ against the alternative $\mathrm{H}_{\mathrm{a}}: \theta_{2} \neq 0$, DEPT Granger causes RGDP. (Equation 6-a);

4-RGDP does not Granger causes DEPT if $\mathrm{H}_{0}: \beta_{2}=0$ against the alternative $\mathrm{H}_{\mathrm{a}}: \theta_{2} \neq 0$, RGDP Granger causes DEPT. (Equation 6-b).

The magnitude and statistical significance of ( $\delta$ 's) in each ECT equation implies long-run causal relationship and measures the tendencies of each variable to return to the equilibrium. On other words the stability of long-run equilibrium can also be judged from the sign and significance of the ECT as if it is negatively significant, it shows convergence towards the equilibrium i.e. a stable long-run equilibrium, While the short-run relationships well be captured through the individual coefficients (i.e. $\gamma_{1}, \gamma_{2}, \theta_{1}, \theta_{2}, \alpha_{1}, \alpha_{2}, \beta_{1}, \beta_{2}$ ) of the difference terms. The Wald test of the explanatory variables indicates the short-run causal effects, and the direction of causality.

\subsection{Data}

The annual series data of RGDP, FINC and DEPT over the period of 1980-2012 were used. All data obtained from CBJ annual reports, Jordanian Statistical year book and annual financial reports issued by Jordanian Islamic banks.

The Consumer Price Index (CPI, $2006=100)$ was used to get the real term of each variable. All data transferred into natural logarithms.

\section{Empirical Results and Discussion}

\subsection{Stationary Test Results}

ADF unit root test is utilized the results are summarized in Table 1. The results indicates that all variables are stationary and integrated of order one in their first difference.

Table 1 . Stationarity test results

\begin{tabular}{lll}
\hline \multirow{2}{*}{ Variables } & \multicolumn{2}{c}{ ADF $\tau$-Statistics } \\
& -1.2749 & First difference \\
\hline LRGDP & -1.3482 & $-6.0326^{*}$ \\
LFINC & -2.5719 & $-5.3175^{*}$ \\
LDEPT & -4.3743 & $-4.6561^{*}$ \\
$1 \%$ Critical Value & -3.6032 & -3.6032 \\
$5 \%$ Critical Value & -3.2380 & -3.2380 \\
$10 \%$ Critical Value & \\
\hline
\end{tabular}

Note: $(*)$ indicate $1 \%$ level of significance. Critical $\tau$-Statistic values obtained from Davidson and MacKinnon (1993). 


\subsection{Co-Integration Test Results}

Before we proceed with co-integration test, we specified the optimal lags length depending on the Akaike Information Criterion (AIC) (Akaike, 1973) and the Schwarz Information Criteria (SIC) (Schwarz, 1978). The appropriate order which is equal one for as it is reported in Table 2.

Table 2. Selection of optimal lags length

\begin{tabular}{lllll}
\hline \multirow{2}{*}{$\begin{array}{c}\text { Number } \\
\text { of Lags }\end{array}$} & \multicolumn{2}{c}{ Financing Model } & \multicolumn{2}{c}{ Deposits Model } \\
\hline 0 & AIC Criterion & \multicolumn{1}{c}{ SIC Criterion } & AIC Criterion & \multicolumn{1}{c}{ SIC Criterion } \\
\hline & 2.006645 & 2.100931 & 1.695676 & 1.789972 \\
2 & $-4.579816^{*}$ & $-4.296927^{*}$ & $-4.741746^{*}$ & $-4.380018^{*}$ \\
3 & -4.438752 & -3.967271 & -4.660290 & -4.082514 \\
\hline
\end{tabular}

Note: * indicates the selected lag order.

Having confirmed that all time series are integrated of the same order, i.e., I(1) the Johansen efficient maximum-likelihood approach (Johansen, 1988) has been applied to detect independently the possibilities existence of co-integration relation among the variables under concerns. Table 3 provides Johansen co-integration test results.

Table 3. Johansen co-integration test results

\begin{tabular}{|c|c|c|c|c|c|c|c|c|c|c|}
\hline \multirow{2}{*}{ Model } & \multicolumn{2}{|c|}{ Hypothesis } & \multicolumn{3}{|c|}{ Trace Test Statistics } & \multicolumn{5}{|c|}{ Maximum Eigenvalue Statistics } \\
\hline & $\mathrm{HO}$ & H1 & statistics & Critical & Sig. $5 \%$ & $\mathrm{H} 0$ & $\mathrm{H} 1$ & statistics & critical & Sig. $5 \%$ \\
\hline \multirow{2}{*}{ Financing } & $\mathrm{r}=0$ & $r \geq 1$ & $17.8^{*}$ & 15.5 & 0.021 & $\mathrm{r}=0$ & $r=1$ & $18.5^{*}$ & 14.1 & 0.013 \\
\hline & $\mathrm{r} \leq 1$ & $\mathrm{r}=2$ & 0.045 & 3.8 & 0.813 & $\mathrm{r} \leq 1$ & $\mathrm{r}=2$ & 0.045 & 3.84 & 0.831 \\
\hline \multirow{2}{*}{ Deposits } & $\mathrm{r}=0$ & $\mathrm{r} \geq 1$ & $19.0^{*}$ & 15.4 & 0.013 & $\mathrm{r}=0$ & $\mathrm{r}=1$ & $18.9 *$ & 14.3 & 0.008 \\
\hline & $\mathrm{r} \leq 1$ & $\mathrm{r}=2$ & 0.112 & 3.9 & 0.737 & $\mathrm{r} \leq 1$ & $r=2$ & 0.112 & 3.84 & 0.737 \\
\hline
\end{tabular}

Notes: Asterisks $(*)$ denotes statistical significance at $5 \%$. $r$ stands for the number of cointegrating vectors.

The results reported in Table 3 indicate the existence of a long-run relation between the two measures of FIBD (FINC and DEPT) and RGDP. The trace statistics reject the null hypotheses of $r=0$ between RGDP and FINC; RGDP and DEPT in favour of the general alternative hypothesis of $r=1$. However, the null hypotheses of $r=1$ and $r=2$ could not be rejected at $5 \%$ level of significance. Likewise, the maximum Eigenvalue test rejects the null hypothesis of no cointegrating vector $\mathrm{r}=0$ at $5 \%$ level of significance in favour of a specific alternative hypothesis that there is one cointegrating vector $r=1$. However, the null hypothesis of $r=1$ and $r=2$ could not be rejected at the $5 \%$ level of significance. The finding that the variables are cointegrated implies the existence of long-run Granger causality in at least one direction (Granger, 1988).

It is, therefore, concluded that there is one cointegrating vector between the EG variable (RGDP) and each of the two measures (FINC and DEPT) of FIBD. This confirms the existence of a long-run relationship between EG variable (RGDP) and the two measures (FINC and DEPT) of FIBD in Jordan.

\subsection{Causality Test Results Based on VECM}

After we confirmed that RGDP and both FIBD measures are cointegrated, the VECM based causality tests are conducted using Johansen cointegrating vectors. The results of the causality tests based on the VECM for both financing and deposits models are presented in Table 4. 
Table 4. Causality tests results based on VECM

\begin{tabular}{llll}
\hline $\begin{array}{l}\text { Financing Model } \\
\text { Variables }\end{array}$ & ECT & $\Delta($ LRGDP(-1)) & $\Delta($ LFINC(-1)) \\
\hline$\Delta$ (LRGDP) & $-0.1463^{*}$ & - & -0.245 \\
& $(-3.341)$ & & $(-1.289)$ \\
$\Delta$ (LFINC) & $-0.0672 *$ & -0.1286 & - \\
& $(-2.585)$ & $-(0.792)$ & \\
\hline Deposits Model & & & $\Delta($ LDEPT(-1)) \\
Variables & ECT & $\Delta$ (LRGDP(-1)) & 0.330 \\
$\Delta$ (LRGDP) & -1.521 & - & $(0.877)$ \\
& $(-0.1260)$ & & - \\
$\Delta$ (LDEPT) & $-0.1463 *$ & 0.3307 & \\
& $(-5.413)$ & $(0.877)$ & \\
\hline
\end{tabular}

Notes: Asterisks $(*)$ denotes statistical significance at $5 \%$. Between parentheses t-value.

According to Table 4 results, the financing model results show that, the coefficient on the ECT for the RGDP (equation: $5-a$ ) is negative and statistically significant at $5 \%$ level in which its t-value equals to $(-2.585)$ with a magnitude equals to (-0.0672) implying that adjustment coefficients are fairly low and deviations from the long-run equilibrium are eliminated slowly. On the other hand, the coefficient on the ECT in the FINC (equation: $5-b)$ equal to (-0.1463) with t-value of (-3.341) is however statistically significant at $5 \%$ level of significance implying that adjustment coefficient is fairly high and deviations from the long-run equilibrium are eliminated rapidly with higher rate of correction relative to RGDP equation ECT. Taken these two findings together, the results imply that there is a bi-directional long-run granger causality between RGDP and FINC.

With regarding to deposits model results, the coefficient on the error-correction term (ECT) for the RGDP (equation: $6-\mathrm{a}$ ) is statistically negative and insignificant at $5 \%$ level in which its t-value equals to $(-1.521)$ and its magnitude is equal to (-0.1260) implying that there is no long-run causality from DEPT to RGDP. While, the coefficient on the error-correction term (ECT) in the DEPT (equation: 6-b) equal to (-0.1463) with t-value of $(-5.41)$ is however statistically negative and significant at $5 \%$ level of significance implying that there is uni-directional long-run causality between LRGDP and LDEPT running from RGDP to DEPT.

Also, the results show that the coefficients on lagged terms for both models are statistically insignificant event at both $5 \%$ and $10 \%$ level of significance. These imply that there is no short-run causality between RGDP and both measures of FIBD, i.e. FINCE and DEPT.

The null hypothesis of finance model that "FINC does not Granger cause RGDP" and "RGDP does not Granger cause FINC" were rejected". Also, the null hypotheses of deposits model that "RGDP does not Granger cause RGDP" was rejected, but the null hypothesis of "DEPT does not Granger cause RGDP" was not rejected.

So, it can be argued that there is a bi-directional long-run causality between RGDP and FINC reflecting a positive contribution of JIB in financing the process of Jordanian social and economic development, the relation appears to be unidirectional relation between RGDP and DEPT running from RGDP to DEPT reflects the excess liquidity problem that JIB suffer from it.

The results are consistent with those obtained by Hassanudin Thaker, et al. (2013) in the Bahrain dual financial system, Farahani and Masood Dastan (2012) in the case of Iran and Indonesia, Abduh and Chowdhury (2012) in the case of Bangladesh and Furqania and Mulyany (2009) for Malaysia.

\section{Conclusion and Recommendation}

\subsection{Conclusion}

In this paper, an attempt has been conducted to explore the relation between FIBD and EG in Jordan over the period of 1980-2012, focusing on Granger causality effects within the context of VECM framework. For this purpose, FINC and DEPT are used as a measure of FIBD, while RGDP used as an indicator of EG.

The results show that there is bi-directional long-run granger causality between RGDP and FINC which reflects positively growth contribution of JIB in the social and economic development process.

The relation appears to be unidirectional relation between RGDP and DEPT running from RGDP to DEPT reflects the excess liquidity problem that JIB suffers from it. With regarding to short-run causality there isn't any significant relations between FIBD and EG. 
We confirm that these results indicate the importance role of a well functioning of Jordanian Islamic banking system and its positive contribution to the economic development process. This suggests that higher FIBD would lead to higher contribution to EG in Jordan.

\subsection{Recommendation}

According to the findings, we recommend the followings: first, the absence of causality running from DEPT to EG may be interpreted by the limited investment opportunities in the Jordanian economy and could be interpreted to the limited investment tools issued by JIB. So, we suggest that JIB managers should work hard to produce new financial instruments and tools satisfy Sharia rules which expected to stimulate positively the Jordan EG. Second, monetary authorities represented by CBJ ought to review the regulations that organized the operations and activities of JIB in order to stimulate its positive contribution to the economic development process and supervision framework infrastructure to meet the present challenges facing Jordanian Islamic banking sector.

Islamic banks should develop its current products in addition to introduce new financial products and services to avoid the problem of narrowing the investments just in real estate. This can go concurrently with the introduction of new nontraditional supported financial institutions and markets based in shareia compliments.

\section{References}

Akaike, H. (1973). Information theory and an extension of the maximum likelihood principle. In B. N. Petrov \& F. Csaki (Eds.), Second International Symposium on Information Theory. Budapest: Symposium, Academia Kiado.

Al-Rajhi, B. (2012). Annual financial report 2012. Retrieved on May 10, 2013, from http://www.alrajhibank.com.jo/ar/about-us/Pages/default.aspx

Central Bank of Jordan. (2012). Annual financial report 2012. Amman: Central Bank of Jordan.

De Gregorio, J., \& Guidotti, E. (1995). Financial development and economic growth. World Development, 23(3), 433-448. http://dx.doi.org/10.1016/0305-750X(94)00132-I

Dickey, D. A., \& Wayne, F. (1979). Distribution of the estimators for autoregressive time series with a unit root. Journal of the American Statistical Association, 74(366a), 427-431. http://dx.doi.org/10.2307/2286348

Enders, W. (1995). Applied econometric time series. Canada: John Wiles and Sons.

Engle, R. F., \& Granger, C. W. J. (1987). Co-integration and error correction: Representation, estimation and testing. Econometrica, 55(2), 251-276. http://dx.doi.org/10.2307/1913236

Granger, C. W. J. (1969). Investigating causal relations by econometric models and cross-spectral methods. Econometrica, 37(3), 424-438. http://dx.doi.org/10.2307/1912791

Granger, C. W. J. (1980). Testing for causality: A personal viewpoint. Journal of Economic Dynamics and Control, 2(1), 329-352. http://dx.doi.org/10.1016/0165-1889(80)90069-X

Granger, C. W. J. (1988). Some recent developments in a concept of causality. Journal of Econometrics, 39(1-2), 199-211. http://dx.doi.org/10.1016/0304-4076(88)90045-0

Granger, C. W. J. (2001). Essays in econometrics: The collected papers of clive W. J. Granger. Cambridge: Cambridge University Press. http://dx.doi.org/10.1017/CBO9780511753978

Gujarati, D. N. (1995). Basic Econometrics (3rd ed.). New York: McGraw-Hill Inc.

Hafas, F., \& Ratna, M. (2009). Islamic banking and economic growth: Empirical evidence from Malaysia. Journal of Economic Cooperation and Development, 30(2), 59-74.

Hassanudin, T., Yousof, H., Hanafi, H., \& Ebrahim. (2013). Do islamic banks contribute to the economic growth than conventional banks? The empirical investigations of bahrain dual banking. International Journal of Science Commerce and Humanities, 1(3), 86-116.

Ilias, S. (2010). Islamic finance: Overview and policy. New York: Congressional Research Service.

Islamic International Arab Bank. (2000). Annual Financial Report 2000. Amman: Islamic International Arab Bank.

Johansen, S. (1988). Statistical analysis of cointegration vectors. Journal of Economic Dynamics and Control, 12(2-3), 231-254. http://dx.doi.org/10.1016/0165-1889(88)90041-3

Johansen, S. (1991). Estimating and testing cointegration vectors in Gaussian vector autoregressive models. 
Econometrica, 59(6), 1551-1580. http://dx.doi.org/10.2307/2938278

Johansen, S., \& Jesulius, K. (1990). Maximum likelihood estimation and inference on cointegration-with application to the demand for money. Oxford Bulletin of Economics and Statistics, 52, 169-210. http://dx.doi.org/10.1111/j.1468-0084.1990.mp52002003.x

Jordan Dubai Islamic Bank. (2010). Annual Financial Report 2011. Amman: Jordan Dubai Islamic Bank.

Jordan Islamic Bank. (1980). Annual Financial Report 1980. Amman: Jordan Islamic Bank.

Kabir, H. M., Benito, S., \& Yu, J. S. (2011). Financial development and economic growth in the organization of islamic conference countries JKAU. Islamic Economy, 24(1), 145-172.

Katos, A. (2004). Econometric: Theory and Practice (1st ed.). Thessaloniki: Zygos.

Kennedy, P. (1996). A Guide to Econometrics (3rd ed.). Cambridge, Mass. USA: The MIT Press.

Muhamad, A. S. B., \& Mohd, A. O. (2012). A study on finance-growth nexus in dual financial system countries: Evidence from Bahrain. World Applied Sciences Journal, 20(8), 1166-1174.

Muhamad, A., \& Mohd, A. (2012). Islamic banking and economic growth: The Indonesian experience. International Journal of Islamic and Middle Eastern Finance and Management, 5(1), 35-47. http://dx.doi.org/10.1108/17538391211216811

Muhamad, A., \& Nazreen, C. (2012). Does islamic banking matter for economic growth in Bangladesh? Journal of Islamic Economics, Banking and Finance, 8(3), 104-113.

Osterwald, L. M. (1992). A note with quintiles of the asymptotic distribution of the maximum likelihood cointegration rank statistics. Oxford Bulletin of Economics and Statistics, 54, 461-472. http://dx.doi.org/10.1111/j.1468-0084.1992.tb00013.x

Sassi, S., \& Goaied, M. (2011). Financial development, islamic banking and economic growth evidence from MENA region. International Journal of Business and Management Science, 4(2), 105-128.

Schwarz, R. (1978). Estimating the dimension of a model. Annuals of Statistics, 6(2), 461-464. http://dx.doi.org/10.1214/aos/1176344136

Yazdan, F., \& Masood, D. (2013). Analysis of islamic banks' financing and economic growth: A panel cointegration approach. International Journal of Islamic and Middle Eastern Finance and Management, 6(2), 156-172. http://dx.doi.org/10.1108/17538391311329842

\section{Copyrights}

Copyright for this article is retained by the author(s), with first publication rights granted to the journal.

This is an open-access article distributed under the terms and conditions of the Creative Commons Attribution license (http://creativecommons.org/licenses/by/3.0/). 